\title{
Perceptions of Contractors and Consultants Toward Application of Greenship Rating Tools on Apartment Buildings in Surabaya
}

\author{
Herry Pintardi Chandra and Paulus Nugraha ${ }^{1}$
}

\begin{abstract}
During the last ten years, the growth of apartment buildings in Surabaya has encountered the bitter experience of global warming, resource depletion, energy scarcity, and other environmental impacts. We cannot avoid them, but we can minimize the negative impacts of global warming. The green building concept is one of the methods to minimize the environmental impact. It takes into account principles of sustainable development in planning, construction, operation, and maintenance. Greenship Rating Tools is used to evaluate and calculate green achievements, prior to green building certification. The aim of this research is to represent the perceptions of contractors and consultants toward application of Greenship Rating Tools on apartment buildings in Surabaya. Based on the data obtained from a questionnaires survey carried out to 41 respondents, the mean value ranking method is used to evaluate the main factors of Greenship. These factors are Appropriate Site Development, Energy Efficiency and Conservation, Water Conservation, Material Resource and Cycle, Indoor Health and Comfort, and Building Environmental Management. In general, the results of this research show that there are a number of differences between perceptions of contractors and consultants toward application of Greenship Rating Tools on apartment buildings in Surabaya. According to the contractors' perception, Visual Comfort is a factor that would easy to be applied, whilst consultants' is Landscape. On the other hand, there are factors that would difficult to be applied. Based on contractors' perceptiom is Climate Change, while consultants' perception is Renewal Energy. In summary, Greenship Rating Tools can be applied on contractors' and consultants' perceptions, whilst there are some sub aspects which difficult to be applied.
\end{abstract}

Keywords-Perception, Application, Greenship Rating Tools

Abstrak-Dalam sepuluh tahun terakhir, pertumbuhan apartemen di Surabaya mendapatkan pengalaman pahit dalam hal pemanasan global, kekosongan sumber daya, kelangkaan energi, dan dampak terhadap lingkungan lainnya. Kita tidak dapat menghindari hal tersebut, tetapi dapat meminimalkan dampak negatif dari pemanasan global. Konsep bangunan hijau atau ramah lingkungan merupakan salah satu metode untuk meminimalkan dampak lingkungan. Metode ini memberikan perhitungan terhadap perancangan, konstruksi, operasi, dan pemeliharaan dalam prinsip pengembangan yang berkelanjutan. Greenship Rating Tools digunakan untuk mengevaluasi dan memperhitungkan pencapaian ramah lingkungan, utamanya untuk mendapatkan sertifikasi bangunan hijau. Tujuan dari penelitian ini adalah merepresentasikan persepsi kontraktor dan konsultan dalam aplikasi Greenship Rating Tools pada bangunan apartemen di Surabaya. Berdasarkan data yang didapatkan dari survei kuesioner terhadap 41 responden, metode peringkat nilai rata-rata dipakai untuk mengevaluasi faktor utama dari bangunan hijau. Faktor tersebut adalah Tepat Guna Lahan, Konservasi dan Efisiensi Energi, Konservasi Air, Siklus dan Sumber Daya Material, Kenyamanan dan Kesehatan Dalam Rumah, dan Manajemen Lingkungan Bangunan. Secara umum, hasil penelitian menunjukkan bahwa ada perbedaan persepsi antara kontraktor dan konsultan dalam aplikasi Greenship Rating Tools dalam bangunan apartemen di Surabaya. Menurut persepsi kontraktor, Kenyamanan Visual adalah faktor yang mudah diaplikasikan, sementara menurut konsultan adalah Lanskap. Di pihak lain, ada faktor yang sulit diaplikasikan. Berdasarkan persepsi kontraktor adalah Peubahan Iklim, dan menurut persepsi konsultan adalah Energi Terbarukan. Kesimpulannya adalah Greenship Rating Tools dapat diaplikasikan sesuai pandangan kontraktor dan konsultan, seraya ada beberapa sub aspek yang sulit diaplikasikan.

Kata kunci-Persepsi, Aplikasi, Greenship Rating Tools

\section{INTRODUCTION}

$\mathrm{D}$ uring the last ten years, the growth of apartment buildings in Surabaya has encountered the bitter experience of global warming, resource depletion, energy scarcity, and other environmental impacts. A competence of construction project stakeholders, especially for contractors and consultants is very important and vital to minimize the impact on the surrounding environment and natural resources, and to operate within the limits stated in the legal permits.

Green building concept is a building, that is designed, built, operated, maintained or reused to protect occupant health, use wisely natural resources and reduce the environmental impact. According to Kubba [1], green

${ }^{1}$ Herry Pintardi Chandra and Paulus Nugraha are with Department of Civil Engineering, Petra Christian University, Surabaya, 60236, Indonesia. Email:herpin@petra. ac.id, pnugraha@petra. ac.id. building is designed for optimum energy efficiency and is constructed with a preference for natural resources, reclaimed, and recycled materials. Several studies have highlighted project management knowledge and skills for green construction by Burnett [2]; and Hwang and $\mathrm{Ng}$ [3]. While many studies have examined the key performance indicators of project success, few have done so in the context of green construction $[4,5]$.

Furthermore, the performing organization implements the environmental management system through the policy, procedures, and processes of environmental planning, environmental assurance, environmental control, and performing continuous improvement activities to minimize the environmental impacts.

Working closely with project stakeholders is needed to achieve environmental sustainability. Skoyles [6] explained that the generation of construction waste is one of the major negative impacts from a construction project on the environment, which can be measured by the 
differences between the amount of the total delivery of materials to the site and the amount of work completed. It is a fact that in construction industry the green building concept evolved and contributed an important role in determined the success of project.

Meanwhile, many countries have developed new concept of rating tools in order to improve the knowledge about the sustainable development. Sustainable development was defined as a development that meets the needs of the present without compromising the ability of future generations to meet their own needs [7]. Then, rating system is a device containing the grains of which refered to aspects of the assessment rating and each grain has the higest rating. Greenship Rating System is an assessment tool developed by Green Building Council of Indonesia (GBCI) to determine whether a building can be declared eligible certified "green building" or not. Each building has different condition and complications of stakeholders. Project stakeholders may have different perceptions and knowledge about green building concept. Therefore, it is important to understand how far the perceptions of contractors and consultants toward application of greenship rating tools. The aim of this research is to represent the perceptions of contractors and consultants toward application of Greenship Rating Tools on apartment buildings in Surabaya.

\section{A. Background}

The Agenda 21 on sustainable development was formulated since The Rio Summit in 1992. Agenda 21 has subsequently been interpreted in several local and sectoral agendas. It introduces several programe areas that impact on the construction industry and delineates action that should be taken to increase sustainability in these ares. One interpretation of more specific relevance to the construction sector is the Habitat II Agenda. International Council for Research and Innovation in Building and Construction (CIB), as the leading international organization for research collaboration in building and construction, recognised early on the importance of environmental concerns and commitment in all its multifaceted activities. It is also a fact that the construction industry and the built environment are the main consumer of resources, energy, and materials. The three principal objectives for the Agenda 21 for sustainable construction are to create a global framework and terminology that will add value to all Agendas, to create an Agenda for CIB activities in the field, and to provide a source document for defining R\&D activities.

Last of all, sustainable construction has different approaches and priorities in different countries. The problem of of poverty and underdevelopment or social equity are sometimes part of the definitions of sustainable construction. The categories of problems can be classified as physical problems linked to the issue of resource, biological problems linked to the life of mankind, and sociological problems linked to the sociopolitical, socio-economic, or socio-cultureal.

According to Agenda 21, the key elements in the sustainable construction are reducing the use of energy sources and depletion of mineral resources; conserving natural areas and bio-diversity; and maintaining the quality of the built environment and management of healthy indoor environment. Some topics related to sustainable construction have also been identified as quality and property value, meeting user needs in the future, prolonged service life, use of local resources, building process, efficient land use, water saving, use of by-products, immaterial services, urban development and mobility, human resources, and local economy.

\section{B. Challenging and rating system in green building}

Green construction can be part of an overall plan for sustainable development with optimum energy, natural, reclaimed, and recycled materials. These consepts provide healthier, more comfortable, and productive indoor environment for occupants by maximizing the efficient usage of energy, water, and raw materials. According to Wang and $\mathrm{Ng}$ [3], challenges faced in green construction can be explained that green construction tend to cost more to construct, technical difficulty during the construction process, risk do to different contract forms, lengthy approval process for new green technologies and recycled materials, unfamiliarity with green technologies, greater communication and interest required among project team members, and more time to implement green construction on site. The challenges in green construction not only to determine the optimal balance between the various constraints of the construction act but also to endevour favour decision without regret in the life cycle of building, and especially in the construction phase.

Richard et al. [8] suggested some key recommendations for sustainable rating tools such as to reduce the barriers between international markets and associated confusion, and it is not possible to use the same rating tools in each country. These preparations should provide some clarification of the assessment tools for sustainable building, which in turn assist stakeholders such as investors, developers, tenants, and government bodies.

Firdaus [9] concluded that the rights, obligations, and responsibilities of a Greenship Professional on the project is not clear and need to explain the legal rules. Every country has their own rating system, for example the United Stated -LEED (Leadership in Energy and Environmental Design), Singapore - Green Mark, and Australia -Green Star.

Furthermore, the Green Building Council of Indonesia published the Greenship Rating Tools, developed in cooperation with related expert, industries, government, academics, and other key organizations in Indonesia. It is used to evaluate and determine green achievements, prior to green building certification. Greenship Rating Tools as a rating system is divided into six aspects as follows: Appropriate Site Development/ASD 16 points, Energy Efficiency \& Conservation /EEC 36 points, Water Conservation/WAC 20 points, Material Resource and Cycle /MRC 12 points, Indoor Health and Comfort/ IHC 20 points, and Building Environment Management 13 points. Depending on the sum of the point values achieved, the building is certified accordingly.

\section{METHOD}

The survey method was adopted to represent the perceptions of contractors and consultants toward 
application of Greenship Rating Tools on apartment buildings in Surabaya.

A questionnaire survey was designed for respondents to assess the application of Greenship Rating Tools. A five- point scale (described as $1=$ very easy to be applied, $2=$ easy to be applied, $3=$ fair to be applied, $4=$ difficult to be applied, $5=$ very difficult to be applied) was adopted where respondents were presented with a statement in the question sheet.The question was phrased to ask the respondents an affirmative response on the main six aspects of greenship rating tools. Each aspect is represented with related indicator. These aspects are Appropriate Site Development (ASD), Energy Efficiency and Conservation (EEC), Water Conservation (WAC), Material Resource and Cycle (MRC), Indoor Health and Comfort (IHC), and Building Environment Management (BEM).

The questionnaire was then developed consisting of question that inquire about the variables that measure the asspect of greenship building. Each question was associated with variables described in the preceding sections. The first part of questionnaire was designed to assess Appropriate Site Development in 7 point. The second part of questionnaire assessed to Energy Efficiency and Conservation in 5 points. The third part is Water Conservation in 6 points. The fourth part is Material Resource and Cycle in 6 points. The fifth is Indoor Health and Comfort in 7 points. The last part is Building Environment Management in 7 points. The questionnaire was administrated via e-mail, hand delivered, and face to face interview to 125 respondents. Among all of these respondents, 43 respondents can not be approached, 27 respondents rejected to answer the questionnare, 41 respondents accepted and cooperatived to answer the questionnaire, and 14 respondents did not return back the questionnaire. The target population of this survey was contractors and consultants. A total of 41 cooperatived respondents, consisting of 31 contractors $(75.61 \%)$ and 10 consultants $(24.39 \%)$, participated in the survey. The complete questionnaire can be gathered from [10]. Mean analysis was performed for each aspect of Greenship Rating Tools. For the purpose of comparison, mean analysis were carried out for different type of respondents, ie. contractors and consultants.

\section{RESULT AND DISCUSSION}

\section{A. Appropriate Site Development (ASD)}

Table 1 presents the mean analysis for Appropriate Site Development (ASD) of Greenship Rating Tools perceived by contractors and consultants.

According to the contractors, application of sub aspect accessability to public area (mean value of 2.77) is the easiest of all sub aspects. Considering the consultants' perceptions, application of sub aspect site landscaping (mean value of 1.90) is the easiest of the others. Meanwhile, micro climate and rain water management are the two sub aspects that can be applied fairly perceived by both contractors and consultants. The shaded boxes highlight these sub aspects in which mean value more than 3.00. It appears that the sub aspect micro climate (mean value of 3.40 for consultants) and rain water management (mean value of 3.10 for contractors) can be applied fairly to achieved the green building concept. For example, to manage rain water can be made by providing the water tank in the field.

Otherwise, perceptions of contractors showed that applications of the sub aspect of accessability to public area, public transportation, micro climate, and rain water management are easier than consultants. On the other hand, based on perceptions of consultants showed that applications of the sub aspect location, bicycle, and site landscaping are easier than constractors' perception.

Last of all, according to the appropriate site development, the contractors found that the sub aspect accessability to public area (mean value of 2.77) was the easiest sub aspect to be applied to achieved green building concept. It is easy to understand, because contractors should prepare the construction site before execution the project. They also need access to public area to get raw materials, equipments, and workers. Then, the consultants thought that site landscaping (mean value of 1.90) was the easiest of all. For this purpose, the consultants should prepare the vegetation landscape area (softscape) which is free from the park (hardscape) located on the upper surface of the land area at least $30 \%$ of the total land area.This fact in line with Agenda 21 such as promoting sustainable land-use planning and management (Chapter 7), and establishing systems for integrated environmental and economic accounting (Chapter 8). Improved land use, easier procedures for land-use change and reforestation would also help much to reduce green houses gas emissions.

\section{B. Energy Efficiency and Conservation (EEC)}

Table 2 presents the mean analysis for Energy Efficiency \& Conservation (EEC) of Greenship Rating Tools perceived by contractors and consultants.

From Table 2 it can be examined that both contractors and consultants agree that the sub aspect daylight is easy to be applied, especially in energy efficiency and conservation. This sub aspect has the mean value of 2.65 for contractors and 2.20 for consultants. The sub aspect daylight is recommended in building design to minimize energy. Contractors and consultants can try to achieve an energy conservation by making commitment and approval from top management to perform various actions in energy conservation such as campaign and institutional policies. Campaign can be done by making sticker, poster, and e-mail. They also use institutional policies in a form of desiignation / team establishment/ personnel task force responsible for energy savings, along with job descriptions.

On the other hand, there are two sub aspects of energy efficiency and conservation that difficult to be applied. These sub aspects are impact of climate change (mean value of 3.19 for contractors) and renewal energy (mean value of 3.80 for consultants). Impact of the climate change can make cost overrun and delay in construction. Renewal energy is one of the important sub aspect in energy efficiency and conservation that need technology development, knowledge, and skill to achieve an ideal green building.

In summary, both contractors and consultants have similar perception that the daylight system is one of the system to minimize energy consumption. It is in line with Chapter 9 in Agenda 21 that focus on promoting sustainable development and the protection of the 
atmosphere through energy development, efficiency and consumption.

\section{Water Conservation (WAC)}

Tabel 3 presents the mean analysis for Water Conservation (WAC) of Greenship Rating Tools perceived by contractors and consultants.

Based on Tabel 3, it can be seen that there are two sub aspects of water conservation that difficult to be applied. These sub factors are water resource (mean value of 3.13 for contractors) and water recycle (mean value of 3.70 for consultants). On the other hand, as can be seen, both the sub aspect rain water usage (mean value of 2.71 for contractors) and reduce water usage (mean value of 2.50 for consultants) are easy to be applied. In this case, we need to develop building system approaches to net zero water consumption, combining rain capture with portable to grey to black water reuse incorporating water efficient technologies and operations both inside and outside buildings. To obtain the construction project success, the project manager must manage the workers and communicate to the team members for the green project in order to convey the sustainable practices in site. These aspects in line with water and urban sustainable development (Chapter 18).

Water management in areas under agricultural use can make the important contribution to the reduction of $\mathrm{CO}_{2}$ emissions.

\section{Material Resource and Cycle (MRC)}

Tabel 4 presents the mean analysis for Material Resource and Cycle (MRC) of Greenship Rating Tools perceived by contractors and consultants.

Similar to the above analyses, Table 4 shows the lowest and highest mean value in material resource and cycle. The lowest mean value is the sub aspect local material (mean value of 2.35 for contractors and 2.00 for consultants). The highest mean value is the sub aspect product with kindly environment process (2.97 for contractors) and reuse of material and building (3.40 for consultants). It means that both contractors and consultants agree to use local material easily in which to obtain green building concept. It is easy to understand, because the local material is very easy and cheap to be found in the local market. This finding in line with Zhang et al. [11] that using green materials would cost from $3 \%$ to $4 \%$ more than conventional construction materials. Materials are as effective cost as possible (therefore replicable) and should follow the sustainability guideliness. The decision making skill is the most critical to effectively mitigate material [3].

In contrasts, all respondents agree that they did not easy to obtain construction product with kindly environment process and reuse material. Furthermore, to resolve this problem, there are specific knowledge area and skills that should be strengthened in order to effective manage green material and green construction [3]. Considering the overall material resource and cycle, both contractors and consultants can develop different ways related to the construction work, for example, (1) develop product and building designs for deconstruction and reuse, (2) develop industry- specific materials flow analysis, accounting methods and tools, and (3) develop and evaluate modular building system technologies and transfer into appropriate markets.

\section{E. Indoor Health and Comfort (IHC)}

Tabel 5 presents the mean analysis for Indoor Health and Comfort (IHC) of Greenship Rating Tools perceived by contractors and consultants. Based on the perceptions of contractors, it can be seen that the sub aspect $\mathrm{CO}_{2}$ monitoring, chemical pollutant, outside view, visual comfort, thermal comfort, and acoustic level are easier to be applied than the perceptions of consultants. There is only one of the sub aspects of Indoor Health and Comfort that difficult to be applied. This sub aspect is $\mathrm{CO} 2$ monitoring that indicated by the mean value of 2.84 for contractors and 3.60 for consultants.

They realize that monitoring $\mathrm{CO}_{2}$ is not easy for them during construction period or building operation. Green construction projects are still relative new in Surabaya. Consequently, team members and workers have little experience. It should provide straight policies and regulations to protect human health and environment issues. No smoking campaign is required to support in door health and comfort.

In contrasts, contractors can maintain sub aspect visual comfort (mean value of 2.29) easily. Then, consultants argued that they can make system to monitor the smoke easily. Both of them in line with a healthy and productive life in harmony with nature. It concerns with health risks as related to the occupation of building. It is in line with promoting cleaner production (Chapter 30). Both of contractors and consultants can develop different ways to keep a good indoor health and comfort, such as : (1) develop personal climate control systems for improved energy and human performance with life cycle cost analysis, (2) develop mixed-mode building systems for new and existing building that support natural conditioning.

\section{F. Building Environment Management (BEM)}

Tabel 6 presents the mean analysis for Indoor Building Environment Management (BEM) of Greenship Rating Tools perceived by contractors and consultants. According to the contractors' opinion, it can be portrayed that there are two sub aspects in building environment management that have the smallest mean score. These sub aspects that indicated easy to be performed are the right procedures and quarantee from the owner (mean value for 2.71) .In addion, related to the consultants' opinion, the smallest mean score (2.40) that indicated the easiet sub aspect to be performed is the quarantee from the owner.

In opposite, contractors said that the sub aspect completely contract (mean value of 2.84) is the most difficulty point to be applied in building environment management. Therefore, to obtain a good contract, the participants should prepare the completely contract before starting the construction project. Furthermore, consultants said that GA/GP as a member of project team, and working with right procedures (both of the two sub aspects indicated by the mean value of 3.30) are the most difficult sub aspect to be applied in building environment management.

In general, the aim of the building environment management is to establish policies regarding the implementation and training efforts to conserve resources and user health within the operation phase. This aim can be achieved by making a good 
communication among the project participants. Communication is especially critical for the green project in order to convey the sustainable practices expected from the team members [3]. Tagaza and Wilson [12] recommended that to support the building environment management and to ensure that sustainable practices are implemented on-site can be achieved by random checking and site visiting. Greenship Professional conducts and involves from the conceptual design stage to operation the project stage. In addition, the main challange is that green technologies are different from conventional technologies [12]. Ahadzie et all. [13] suggested that to reach a good project performance outcome, task performance behaviours and contextual performance behaviours are required. It may help to build a good project team and obtain the right procedures in green construction.

In spite of the different perceptions between contractors and consultants toward in greenship rating tools, they must to support green building concept. In order to successfully implement the green building principle, active communication must be maintained with all stakeholders to provide clarification of the project's environmental objectives and the environmental implications of its execution. The project stakeholders should aware and encourage the application of all aspects of green building, which entails addressing three distinct set of requirements, namely: (1) Mandatory statutory environmental requirements, imposed by legislation and enforced by statutory third party authorities in the region where the project to be constructed; (2) Customer environmental requirements contained in condition of contract, defining how they require specific safety requirements to be undertaken and administered, and the technical safety performance and acceptance criteria; and (3) Requirements of the performing organization to satisfy the commercial need, and increase reputation in the market place [14].

\section{CONCLUSION}

The finding of this study provides valuable insight for perceptions of contractors and consultants toward greenship rating tools on apartment building in Surabaya. Since contractors and consultants such as primary project stakeholders play an important role in the greenship building, it is therefore esential to know their perceptions toward six aspects of greenship rating tools. As a results, the aim of this study can be identified by obtaining the factors that would easy and difficult to be applied. According to the contractors' perceptions, there are some factors that would easy to be applied, such as the accessability to public area (mean value of 2.77 ), daylight (mean value of 2.65), rain water usage (mean value of 2.71), local material (mean value of 2.35), visual comfort (mean value 2.29), and right procedures and quarantee from the owners (mean value of 2.71). Contractor as the executor of the project should minimize the impact on the surrounding environment and natural resources and to operate within the limits stated in legal permits. By using local material, rain water, and right procedures, they argued that they can minimize project cost, and achieve environmental conservation and improvement.
Then, based on the perceptions' consultants, these easy factors are site landscaping (mean value of 1.90), daylight (mean value of 2.20), reduce water usage (mean value of 2.50), local material (mean value of 2.00), smoke monitoring system (mean value of 2.00), and quarantee from the owners (mean value of 2.40). Designers are experts in their own field and they conform to known and accepted practices. At the design stage, compromises must be reached between all the competing requirements within in one or more of the limiting constraints. Every components in every system must be able to make its proper contribution to the functional performance of that systems. Consultants suggested that innovation can be reached by making a good site landscaping design, reducing water usage, and using local material. Innovation provides minimum cost projects. The success of a project is highly correlated with the quality and depth of the plans prepared during the design phase.

Otherwise, contractors recommended some factors that would difficult to be applied, such as micro climate (mean value of 3.06), impact of climate change (mean value of 3.19), alternative water resource (mean value of 3.13 ), product with kindly environment process (mean value of 2.97), $\mathrm{CO}_{2}$ monitoring (mean value of 2.84), and completely contract (mean value of 2.84). In addition, the difficult aspect to be applied perceived by consultants are micro climate (mean value of 3.40), renewal energy (mean value of 3.80 ), water recycle (mean value of 3.70 ), reuse of material and building (3.40), $\mathrm{CO}_{2}$ monitoring (mean value of 3.60), and GA/GP as a member of project team, and right procedures (mean value of 3.30).

Green construction takes into account principles of sustainable development in planning, construction, operation and maintenance. Consequently, both consultant as a planner and contractor as an executor of the project need to better understanding the whole aspect in green building. Environmental management requires ensuring that the project management system employs all processes needed to meet the project requirements, and that processes take into consideration the environment. The project stakeholders should aware and encourage the application of all aspects of green building, such as: mandatory statutory environmental requirements; customer environmental requirements contained in condition of contract; and requirements of the performing organization to satisfy the commercial need.

In summary, Greenship Rating Tools can be applied on contractors' and consultants' perceptions, while there are some sub aspects which difficult to be applied. At the design stage, the role of consultant is to achieve the high quality detailed design of the process or of the system's elements and components. On the other hand, contractor as the executor of the project should deliver the project based on the design and minimize the impact on the surrounding environment and natural resources and to operate within the limits stated in legal permits. Last but not least, in the future all of these aspects of green building should be applied in site by both contractors and consultants. The most significant limitation of this study had to do with the size and makeup of the sample surveyed. Future research should complete this study to 
get the whole portrait of green building.

TABLE 1.

MEAN COMPARISON OF CONTRACTORS AND CONSULTANTS PERCEPTIONS IN APPROPRIATE SITE DEVELOPMENT

\begin{tabular}{|c|c|c|c|}
\hline \multirow[b]{2}{*}{$\begin{array}{c}\text { Sub } \\
\text { Aspect }\end{array}$} & \multirow[b]{2}{*}{ Description } & \multicolumn{2}{|c|}{ Mean } \\
\hline & & $\begin{array}{c}\text { Contrac } \\
\text { tors }\end{array}$ & $\begin{array}{c}\text { Consul } \\
\text { tants }\end{array}$ \\
\hline ASD 1 & Location & 2.84 & 2.60 \\
\hline ASD 2 & Accessability to public area & 2.77 & 3.00 \\
\hline ASD 3 & Public transportation & 2.81 & 3.30 \\
\hline ASD 4 & Bicycle & 2.90 & 2.10 \\
\hline ASD 5 & Site landscaping & 2.81 & 1.90 \\
\hline ASD 6 & Micro climate & 3.06 & 3.40 \\
\hline ASD 7 & Rain water management & 3.10 & 3.20 \\
\hline
\end{tabular}

TABLE 3 .

MEAN COMPARISON OF CONTRACTORS AND CONSULTANTS PERCEPTIONS IN WATER CONSERVATION/WAC

\begin{tabular}{clll}
\hline \multirow{2}{*}{$\begin{array}{c}\text { Sub } \\
\text { Aspect }\end{array}$} & \multicolumn{1}{c}{ Description } & $\begin{array}{c}\text { Mean } \\
\text { Contrac }\end{array}$ & $\begin{array}{c}\text { Consul } \\
\text { tants }\end{array}$ \\
\hline WAC 1 & Reduce water usage & 2.94 & 2.50 \\
WAC 2 & Water fixtures & 2.84 & 2.70 \\
WAC 3 & Water recycle & 3.06 & 3.70 \\
WAC 4 & Alternative water resource & 3.13 & 2.80 \\
WAC 5 & Rain water usage & 2.71 & 2.70 \\
WAC 6 & Efficiency of landscape water & 2.87 & 3.00 \\
\hline \hline
\end{tabular}

TABLE 5 .

MEAN COMPARISON OF CONTRACTORS AND CONSULTANTS PERCEPTIONS IN INDDOR HEALTH AND COMFORT/IHC

\begin{tabular}{|c|c|c|c|}
\hline \multirow[b]{2}{*}{$\begin{array}{c}\text { Sub } \\
\text { Aspect }\end{array}$} & \multirow[b]{2}{*}{ Description } & \multicolumn{2}{|c|}{ Mean } \\
\hline & & $\begin{array}{c}\text { Contrac } \\
\text { tors }\end{array}$ & $\begin{array}{c}\text { Consul } \\
\text { tants }\end{array}$ \\
\hline IHC 1 & $\mathrm{CO}_{2}$ monitoring & 2.84 & 3.60 \\
\hline $\mathrm{IHC} 2$ & Smoke monitoring system & 2.39 & 2.00 \\
\hline IHC 3 & Chemical pollutant & 2.58 & 3.50 \\
\hline IHC 4 & Outside view & 2.77 & 3.00 \\
\hline IHC 5 & Visual comfort & 2.29 & 2.40 \\
\hline IHC 6 & Thermal comfort & 2.65 & 2.80 \\
\hline IHC 7 & Acoustic level & 2.67 & 3.10 \\
\hline
\end{tabular}

\section{REFERENCES}

[1] S. Kubba, "Green Construction Project Management and Oversight”. Elsevir, USA., 2010.

[2] J. Burnett, "City Buildings-Eco Labels and Shades of Green". Landscape and Urban planning 83, pp. 29-38, 2007.

[3] G.B.Hwang, and W.J. Ng, "Project Management Knowledge and Skills for Green Construction: Overcoming Challenges". International Journal of Project Management, Vol. 31, pp. $272-$ 284, 2013

[4] E.W.M. Lam, A.P.C. Chan, and D.W.M. Chan, "Benchmarking the Performance of Design-Build Projects". Development of Project Success Index. Benchmarking, An international Journal, Vol. 14, No.5, pp.624-638, 2007.

[5] S.H. Park, "Whole Life Performance Assessment: Critical Success Factors". Journal of Consteruction Engineering and Management, Vol. 135, No.15, pp.1146-1161, 2009.

[6] E.R. Skoyles, "Waste Prevention on Site", Mitchell, London, 1987.

[7] Agenda 21 on Sustainable Construction, CIB Report Publication 237, Juli, 1999.

[8] R. Richard, A. Bilos, S. Wilkinson, and K.W. Schculte, "International Comparison of Sustainable Rating Tools", JOSRE, Vol. 1., No.1, 2009.
TABLE 2.

MEAN COMPARISON OF CONTRACTORS AND CONSULTANTS PERCEPTIONS IN ENERGY EFFICIENCY \& CONSERVATION

\begin{tabular}{cllc}
\hline \hline Sub & \multicolumn{1}{c}{ Description } & \multicolumn{2}{c}{ Mean } \\
Aspect & \multicolumn{1}{c}{ tors } & $\begin{array}{c}\text { Consul } \\
\text { tants }\end{array}$ \\
\hline EEC 1 & Energy efficiency & 2.84 & 2.30 \\
EEC 2 & Daylight & 2.65 & 2.20 \\
EEC 3 & Ventilation & 3.03 & 2.40 \\
EEC 4 & Impact of climate change & 3.19 & 3.30 \\
EEC 5 & Renewal energy & 3.00 & 3.80 \\
\hline \hline
\end{tabular}

TABLE 4.

MEAN COMPARISON OF CONTRACTORS AND CONSULTANTS PERCEPTIONS IN MATERIAL RESOURCE AND CYCLE /MRC

\begin{tabular}{|c|c|c|c|}
\hline \multirow[b]{2}{*}{$\begin{array}{c}\text { Sub } \\
\text { Aspect }\end{array}$} & \multirow[b]{2}{*}{ Description } & \multicolumn{2}{|c|}{ Mean } \\
\hline & & $\begin{array}{l}\text { Contrac } \\
\text { tors }\end{array}$ & $\begin{array}{c}\text { Consul } \\
\text { tants }\end{array}$ \\
\hline MRC 1 & Reuse of material and building & 2.71 & 3.40 \\
\hline MRC 2 & $\begin{array}{l}\text { Product with kindly } \\
\text { environment process }\end{array}$ & 2.97 & 3.30 \\
\hline MRC 3 & $\begin{array}{l}\text { Non Ozon Depletion System } \\
\text { (ODS) usage }\end{array}$ & 2.77 & 3.30 \\
\hline MRC 4 & Certified wood & 2.58 & 2.30 \\
\hline MRC 5 & Modular design & 2.68 & 2.30 \\
\hline MRC 6 & Local material & 2.35 & 2.00 \\
\hline
\end{tabular}

TABLE 6.

MEAN COMPARISON OF CONTRACTORS AND CONSULTANTS PERCEPTIONS IN BUILDING ENVIRONMENT MANAGEMENT

\begin{tabular}{clcc}
\hline \hline \multirow{2}{*}{$\begin{array}{c}\text { Sub } \\
\text { Aspect }\end{array}$} & \multicolumn{1}{c}{ Description } & $\begin{array}{c}\text { Mean } \\
\text { Contrac } \\
\text { tors }\end{array}$ & $\begin{array}{c}\text { Consul } \\
\text { tants }\end{array}$ \\
\hline BEM 1 & GA/GP as a member of project & 2.74 & 3.30 \\
& team & & \\
BEM 2 & Pollutant of construction process & 2.77 & 2.80 \\
BEM 3 & Waste management & 2.81 & 3.00 \\
BEM 4 & Right procedures & 2.71 & 3.30 \\
BEM 5 & Submission implementation & 2.74 & 3.00 \\
& green building data & & \\
BEM 6 & Completely contract & 2.84 & 2.60 \\
BEM 7 & Quarantee from the owner & 2.71 & 2.40 \\
\hline
\end{tabular}

[9] A. Firdaus, "Identification of the Greenship Professional Competence on Green Building Project", 15008068.

[10] H. Warsito, dan M.A. Prawatyo, "Tanggapan Terhadap Kemudahan Penerapan Greenship Rating Tools Pada Bangunan Apartemen d Surabaya". Skripsi No.21011854/SIP/2012,

Fakultas Teknik Sipil dan Perencanaan Universitas Kristen Petra Surabaya, 2012.

[11] X.L. Zhang, L.Y. Shen, and Y.Z. Wu, "Green Strategy for Gaining Competitive Advantage in Housing Development: a China Study". Journal of Cleaner Production, Vol. 19, No.1, pp.157-167, 2011.

[12] E. Tagaza, and J.L. Wilson, "Green Building: Drivers and Barriers e Lessons Learn from Five Melbourne Developments". Report for Building Commision by University of Melbourne and Business Outlook and Evaluation., 2004.

[13] D.K. Ahadzie, D.G. Proverbs, and P. Olomolaiye, "Towards Developing Competency-Based Measures for Construction Project Managers: Should Contextual Behaviours be Distinguished from Task Behaviours?'.International Journal of Project Management, Vol. 26, pp.631-645, 2008.

[14] Project Management Institute," Construction Extention to The PMBOK \$ Guide Third edition", Second edition, 2007. 